\title{
Missing fossils, MOLECUlar ClOCKS, AND THE ORIGIN OF THE MelastomataCEAE ${ }^{1}$
}

\author{
Robert J. Morley ${ }^{2,4}$ AND CHristopher W. DiCK ${ }^{3}$ \\ ${ }^{2}$ School of Geography and Environmental Science, Monash University, Victoria 3800, Australia, and Department of Geology, \\ Royal Holloway University, Egham, Surrey TW20 0EX, UK; and \\ ${ }^{3}$ Smithsonian Tropical Research Institute, Unit 0948, APO AA 34002-0948, USA
}

\begin{abstract}
In a recent analysis of the historical biogeography of Melastomataceae, Renner, Clausing, and Meyer (2001; American Journal of Botany 88(7): 1290-1300) rejected the hypothesis of a Gondwana origin. Using a fossil-calibrated chloroplast DNA (ndhF) phylogeny, they placed the early diversification of Melastomataceae in Laurasia at the Paleocene/Eocene boundary (ca. $55 \mathrm{Ma}$ ) and suggested that long-distance oceanic dispersals in the Oligocene and Miocene (34 to $5 \mathrm{Ma}$ ) account for its range expansion into South America, Africa, and Madagascar. Their critical assumption - that oldest northern mid-latitude melastome fossils reflect tribal ages and their geographic origins - may be erroneous, however, because of the sparse fossil record in the tropics. We show that rates of synonymous nucleotide substitutions derived by the Renner et al. (2001) model are up to three times faster than most published rates. Under a Gondwana-origin model advocated here, which includes dispersals from Africa to Southeast Asia via the "Indian ark" and emphasizes filter rather than either sweepstakes dispersal or strict vicariance, rates of nucleotide substitution fall within the range of published rates. We suggest that biogeographic reconstructions need to consider the paucity of Gondwanan fossils and that frequently overlooked interplate dispersal routes provide alternatives to vicariance, boreotropical dispersal, and long-distance oceanic dispersal as explanations for the amphi-oceanic disjunctions of many tropical rain forest plants.
\end{abstract}

Key words: chloroplast DNA; Melastomataceae; palynology; plate tectonics; synonymous substitution rates; tropical rain forests.

In a recent global evaluation of the biogeography and fossil record of tropical plants within a plate tectonic framework, Morley (2000; pp. 260-262) described three main centers of tropical (megathermal) flowering plant diversification during the Late Cretaceous and earliest Tertiary: (1) one across the northern mid-latitudes (Laurasia), characterized by such families as Actinidiaceae, Icacinaceae, Rutaceae, Menispermaceae, Theaceae, and Zingiberaceae; (2) an equatorial center (West Gondwana) with, among others, Annonaceae, Leguminosae, Myrtaceae, and Arecaceae; and (3) a southern mid-latitude center (Southern Gondwana) that harbored very old families such as Chloranthaceae and Winteraceae and became a center of radiation for such families as Proteaceae. The Northern Hemisphere center is particularly noteworthy because many of its modern taxa display amphi-Pacific distributions (being confined to the Neotropics and Southeast Asia, but absent from Africa) or are relict to Southeast Asia. These distributions reflect the different dispersal opportunities of Boreotropical (Laurasian) rain forest taxa to find refuge in the low latitudes as global climates deteriorated during the mid-Tertiary (Morley, 2001).

Melastomataceae is an important rain forest family, but was excluded from the Morley (2000) evaluation because of its very limited macrofossil record at low latitudes in the older Tertiary and because its pollen is difficult to distinguish from that of Combretaceae (cf. Muller, 1981). Melastomataceae exhibits its greatest diversity in the Neotropics (ca. 3000 species), followed by Southeast Asia $(\sim 1000)$, with moderate di-

\footnotetext{
${ }^{1}$ Manuscript received 5 November 2002; revision accepted 1 May 2003.

The authors thank Keith Richards and Paul Waton for unpublished records of heterocolpate pollen from Colombia and Borneo, Andrew J. Crawford for helpful comments, and an anonymous reviewer for improvements to the manuscript.

${ }^{4}$ Present address: Palynova/PT Eksindo Pratama, Villa Indah Pajajaran, J1 Kertarajasa No. 12A, Bogor, Indonesia 16153. E-mail: pollenpower@indo. net.id.
}

versities in Africa (=240) and Madagascar $(=225)$ (Renner, 1993). Its sister family, Memecylaceae, is also pantropical. The biogeographic patterns of Melastomataceae are typical of a Gondwana-derived lineage (Raven and Axelrod, 1974; Gentry, 1982; Jacques-Félix, 1994), which has become the established view.

In a recent molecular systematic interpretation Renner et al. (2001) provided a radically different hypothesis on the biogeographic history of the Melastomataceae. With reference to a fossil-calibrated molecular clock, they placed the initial diversification of the family in Laurasia in the Paleocene/Eocene (ca. 55 million years [Ma]; Tertiary epoch boundaries follow Berggren et al. [1995], Cretaceous stage boundaries follow Harland et al. [1989]), and its pantropical distribution was attributed to long-distance dispersal during the Oligo-Miocene (34 to $5 \mathrm{Ma}$ ). This conclusion, subsequently expanded by Renner and Meyer (2001), is remarkable since it implicates transoceanic dispersal (possibly by winds) as the primary mode of interplate range expansion, and it implies that much of the species diversity of Melastomataceae is younger than previously thought.

The assumption that the earliest fossil records of particular clades of Melastomataceae reflect their age and geographic origin may be erroneous, however, due to regional biases in the angiosperm fossil record.

Regional bias in the angiosperm macrofossil recordThe Tertiary plant macrofossil record is strongly biased to North America, Europe, and northern Asia, where studies of angiosperm leaf and seed fossils have a long tradition. In comparison, other regions, especially the Southern Hemisphere, have provided little data (Collinson, 1990). This bias must be taken into account when reviewing fossil evidence for angiosperms. The macrofossil record for virtually each Tertiary epoch of North America and Europe is particularly prolific, with only the North American Pliocene being poorly 
studied (Manchester, 1999), but even here, strong bias is seen in the fossil melastome record. Seeds (Melastomeae) are known only from the Eurasian Miocene (e.g., Collinson and Pingen, 1982; Mai, 2000). There are no records from North America, despite the common occurrence in wetlands from Southeastern USA to Ontario of the temperate swamp herb Rhexia, which is a likely candidate for the Eurasian seeds. Similarly, although numerous leaf fossils are known from North America (e.g., Hickey, 1977; Wehr and Hopkins, 1994), probably referable to Miconieae/Merianieae, no leaves referable to the family are known from Eurasia. The macrofossil bias may be due to differences in the ecology and taphonomy of melastomes in these regions.

In tropical regions, the fossil record is strongly biased with respect to collecting intensity. In South America, numerous macrofossil studies have focused on the Mio-Pliocene with more than 50 papers dealing with Neogene macrofloras. These have yielded melastome fossils approximately in proportion to the present-day diversity of the family (Burnham and Graham, 1999). However, Neotropical Palaeogene and Late Cretaceous macrofloras are poorly described with only a scattering of references for the Eocene (many dealing with single fossils rather than floras) and hardly any from the critical Paleocene and Late Cretaceous. There is one melastome record from the "Oligo-Miocene" of Panama (Duarte, 1956), and Huertas (1977) discussed one leaf fossil from the Eocene of Colombia (considered Oligocene, ca. 30 Ma, by Renner et al. [2001]).

There are no melastome fossils from Africa, where most macrofossil studies are based on fossil woods, but there is a single reference to Memecylon leaves (Memecylaceae) from the Indian Oligocene (Awasthi and Mehrota, 1995). The paucity of plant macrofossils from the Neotropical and African Tertiary are likely due to lack of study and limited accessibility of appropriate outcrops.

In Southeast Asia and Indochina, the rock record is highly biased toward the Neogene, and this bias is reflected in the plant macrofossil record (Bande and Prakash, 1986). Eocene plant macrofossil-bearing sediments are of extremely limited occurrence, and Paleocene outcrops are virtually nonexistent, except perhaps in Myanmar; no plant macrofossils are known from the Late Cretaceous. The only fossils referable to Melastomataceae are of leaves and have been attributed to Astronia. These have been recorded from the Miocene of Sabah (Geyler, 1887) and Sumatra (Krausel, 1929).

The pollen record of Melastomataceae-The pollen of Melastomataceae, Memecylaceae, Oliniaceae, Penaeaceae, and Rhynchocalycaceae is uniformly heterocolpate. Crypteroniaceae includes heterocolpate (Axinandra, Dactylocladus) and bisyncolpate (Crypteronia) pollen, whereas that of Alzateaceae is tricolporate (Muller, 1975). It is difficult to differentiate the heterocolpate pollen of Melastomataceae sensu lato from that of Combretaceae (also Myrtales). The most distinctive difference is pollen size, with many melastome genera having smaller pollen. In South America, palynologists have been confident in referring very small heterocolpate pollen from the Plio-Pleistocene to Miconia (van der Hammen and Gonzaléz Guzman, 1963) and in Southeast Asia, small grains are generally referred to the Medinilla type (R. J. Morley, unpublished data) and occur back to the Early Miocene. The oldest published heterocolpate pollen is from the Paleocene of Colombia (Heterocolpites palaeocenica, van der Hammen and Garcia de Mutís, 1966; attributed by the authors to probable Melastomataceae), and recently this species has been recorded as a rare element from the latest Maastrichtian (70-65 Ma) of the same area by K. Richards (KRA International, personal communication). Elsewhere, the oldest published records are from the Late Eocene of West Africa (Salard-Chebaldaeff, 1981). Muller (1981) refers the latter to Combretaceae, but affinity with Melastomataceae is an equal possibility. The oldest heterocolpate pollen records from Southeast Asia are also of Late Eocene age, from the Mankalihat Peninsula in Borneo (P. Waton, Corelab, personal communication). The oldest Indian records are from the Early Miocene (Rao and Ramanujam, 1982). The fossil pollen record, although not conclusively indicating the presence of Melastomataceae, is consistent with an origin in Western Gondwana followed by Eocene dispersal to Southeast Asia via the "Indian ark" (see later).

Gondwana origins revisited-The first appearance of Melastomataceae leaves in the Eocene of North America and Melastomeae seeds in the early Miocene of Europe and Asia may reflect colonization from Gondwanan lineages for which there is no fossil record (the "missing fossils" scenario). In order to evaluate this hypothesis it was first necessary to assess the strength of the Renner et al. (2001) molecular data in falsifying the Gondwana model. We did this by calibrating the synonymous nucleotide substitution rates of the $n d h F$ data set, based on (1) minimum ages of dispersal corridors among the Gondwana fragments (Fig. 1) and (2) age of earliest Melastomataceae and Melastomeae fossils, as in Renner et al. (2001). We compare these silent substitution rates to a range of published estimates. We then provide an alternative biogeographic hypothesis for the pantropical expansion of the family.

\section{MATERIALS AND METHODS}

Gondwana dispersal model - In our model, we dated the ages of key nodes of the Melastomataceae phylogeny (Renner, 2001) through reference to the fossil record and tectonic plate separations. Key dates were positioned on the basis of the oldest record of Myrtaceae pollen at 88 Ma (node B in Fig. 1) and the separation of Madagascar and the Indian Plate at about $68 \mathrm{Ma}$ (nodes $\mathrm{L}$ and $\mathrm{K}$ ). Other divergences were positioned using the relative branching order of the $n d h \mathrm{~F}$ phylogeny (Renner et al., 2001). Using this approach, we estimated the origin of the tribe Melastomeae at $76 \mathrm{Ma}$.

Molecular analysis - We focused our molecular analysis on the Melastomeae tribe, whose $23 \mathrm{Ma}$ seed fossils were used by Renner et al. (2001) to calibrate the $n d h \mathrm{~F}$ molecular clock. Melastomeae is pantropical, with representatives in North and South America, Africa, India, and Madagascar. The Renner et al. (2001) analysis included 27 species, representing 17 genera. The North American genus Rhexia ( $R$. mariana and $R$. virginica) was basal in their analysis. The genera Nepsera, Comolia, and Aciotis formed another relatively basal group. We downloaded the $n d h \mathrm{~F}$ sequences of the Melastomeae from Genbank (accession numbers in Renner et al., 2001; alignments available from C. W. Dick) and for generic representatives of other Melastomataceae. The sequences were aligned manually using the program Sequence Alignment Editor v. 2.0 (A. Rambaut, Oxford University, UK).

Our genetic analysis focused on synonymous (silent) nucleotide substitutions, those that do not result in the replacement of an amino acid. We focused on silent rather than total nucleotide substitutions because silent rates are not constrained by natural selection to maintain protein function and are therefore comparable across different protein-coding chloroplast genes (Muse and Gaut, 1997). Gaut et al. (1997), for example, found no significant differences in silent substitution rates in $r b c \mathrm{~L}$ and $n d h \mathrm{~F}$ in the Poaceae. We calculated the synonymous distances (number of synonymous substitutions per synonymous 


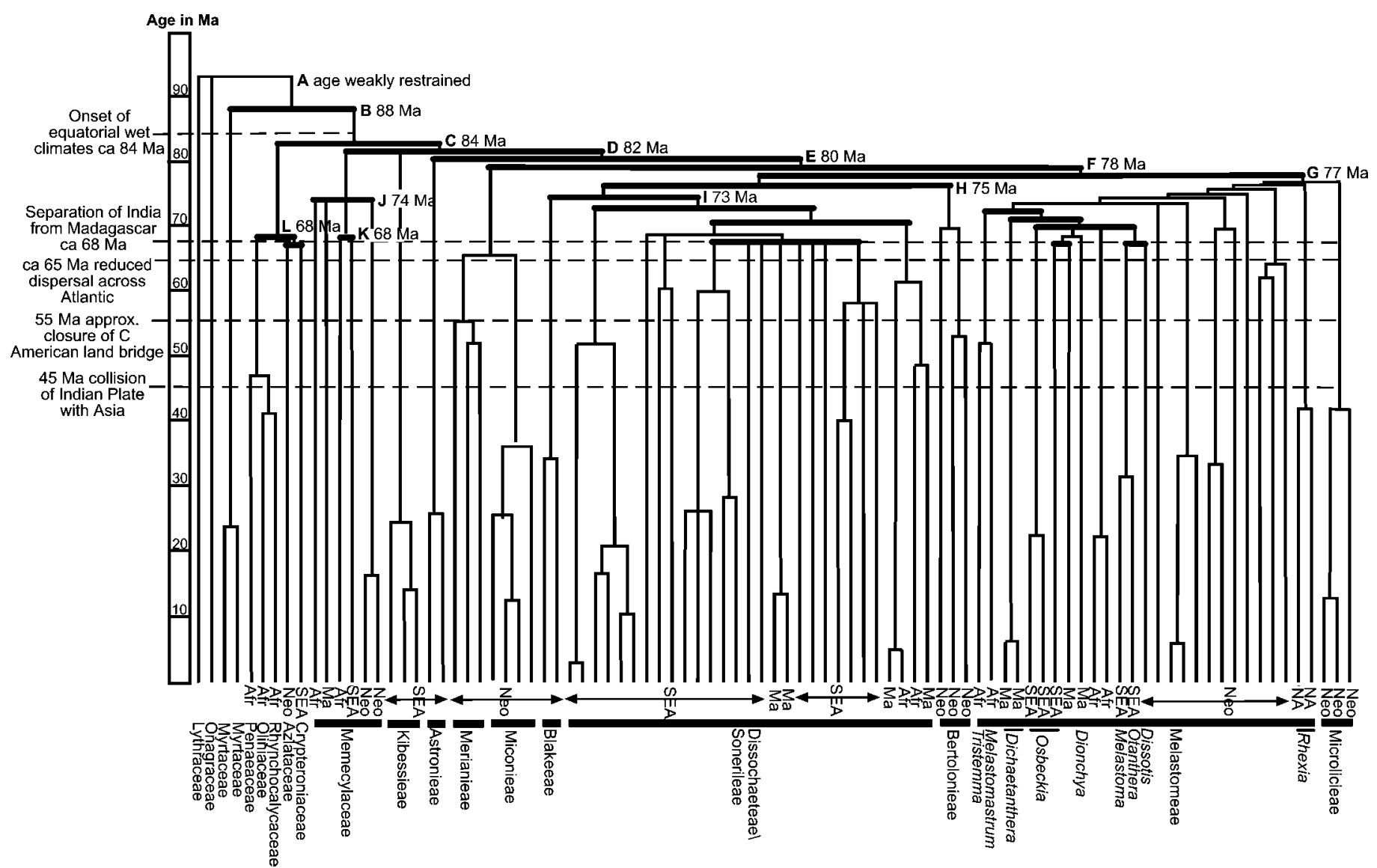

Fig. 1. Phylogenetic hypothesis for Melastomataceae. Branching patterns are based on Fig. 1 of Renner et al. (2001), but divergence times are based on known dispersal corridors between the post-Gondwana land masses and are indicated by heavy horizontal lines. (A) No direct restraints from fossil record; (B) oldest Myrtaceae pollen in Africa, at about $88 \mathrm{Ma}$; (C) small sister families separate from Melastomataceae/Memecylaceae in Africa at about $84 \mathrm{Ma}$; (D) Memecylaceae and Kibessieae separate from mainstream Melastomataceae at about $82 \mathrm{Ma}$; (E) Astronieae separate from mainstream Melastomataceae at about $80 \mathrm{Ma}$; (F) South American Miconieae/Meraniaeae separate from pantropical Melastomataceae at about 78 Ma; (G) differentiation of Microlicieae/Melastomeae from Dissochaeteae/Sonerileae/Bertolonieae at about $77 \mathrm{Ma}$; (H) differentiation of South American Bertolonieae from Blakeeae/Dissochaeteae/Sonerileae at about $75 \mathrm{Ma}$; (I) South American Blakeeae differentiate from Dissochaeteae/Sonerileae at about 73 Ma; (J) Memecylon in Africa, Madagascar, and India at about $74 \mathrm{Ma}$; (K) Memecylon in Madagascar and India at about $68 \mathrm{Ma}$; (L) ancestor to sister families in South America, Africa, and/or India at about $68 \mathrm{Ma}$. Afr = Africa; Ma = Madagascar; NA = North America; Neo = Neotropics; SEA = Southeast Asia.

site, denoted $K_{\mathrm{S}}$ ) in the program MEGA 2.1 (Kumar et al., 2001). We employed the method of Li-Wu-Luo (Li et al., 1985), in which one-third of the two-fold and all of the four-fold degenerate sites are considered synonymous sites. The Li-Wu-Luo method also factors the different frequencies of transitions and transversions. We coded ambiguous sites as missing data and analyzed gaps through the pairwise deletion option. Confidence limits were computed through bootstrap resampling with 500 replicates.

Silent substitution rates $\left(R_{\mathrm{S}}\right)$ were calculated using the formula $R_{\mathrm{S}}=$ $K_{\mathrm{S}} / 2 T$, where $T$ is the time of divergence of the clade. Renner et al. (2001) used $23 \mathrm{Ma}$ fossil Melastomeae seeds to mark the age of divergence of the Melastomeae, whereas as noted above, we applied a divergence time of 76 Ma based on ages of plate tectonic separations (Fig. 1). We compared estimates to a range of values published for other flowering plants: Wolfe et al. (1987) estimated a range of 1.0 to $3.0 \times 10^{-9}$ substitutions per silent site per year for angiosperms based on a comparison of eight chloroplast genes from monocots and dicots $(T=140 \mathrm{Ma})$ and wheat and maize $(T=20-40 \mathrm{Ma})$. Zurawski and Clegg (1987) calculated an $R_{\mathrm{S}}$ of $1.3 \times 10^{-9}$ based on chloroplast DNA divergences between spinach and tobacco. Xiang et al. (2000), using a detailed northern latitude fossil record of Cornus, calculated $R_{\mathrm{S}}$ of $1.02-1.42 \times 10^{-9}$ for $r b c \mathrm{~L}$ and then obtained similar values from 10 sister taxa pairs (from 10 families) that display an East Asian and eastern North American disjunction.

\section{RESULTS}

The mean synonymous distance $\left(K_{\mathrm{s}}\right)$ among the Melastomeae genera was $0.109 \pm 0.013$ (means $\pm 1 \mathrm{SE}$ ) and was based on 330 synonymous sites. The synonymous distance involving Rhexia and all other Melastomeae was $0.137 \pm 0.021$, while the mean for the Nepsera/Aciotis/Comolia vs. all other Melastomeae was $0.156 \pm 0.021$. Under the Gondwana model $(T=76 \mathrm{Ma})$, these divergences correspond to rates of $0.9 \pm$ $0.014 \times 10^{-9}$ and $1.03 \pm 0.14 \times 10^{-9}$ synonymous substitutions per synonymous site per year. Applying the seed fossilbased $T=23$ Ma to the same nodes produces estimates of $R_{\mathrm{s}}$ of $2.978 \pm 0.457 \times 10^{-9}$ and $3.391 \pm 0.457 \times 10^{-9}$.

Estimates of $R_{\mathrm{s}}$ under the Gondwana scenario are roughly three times slower than those of the Renner et al. (2001) analysis; yet our estimates fall closer to most of the published synonymous rate estimates for chloroplast genes. Our analysis of synonymous distances shows that the $n d h \mathrm{~F}$ data have not falsified the "missing fossils" or Gondwana hypothesis; in fact the data appear to support Late Cretaceous models of diversification. 


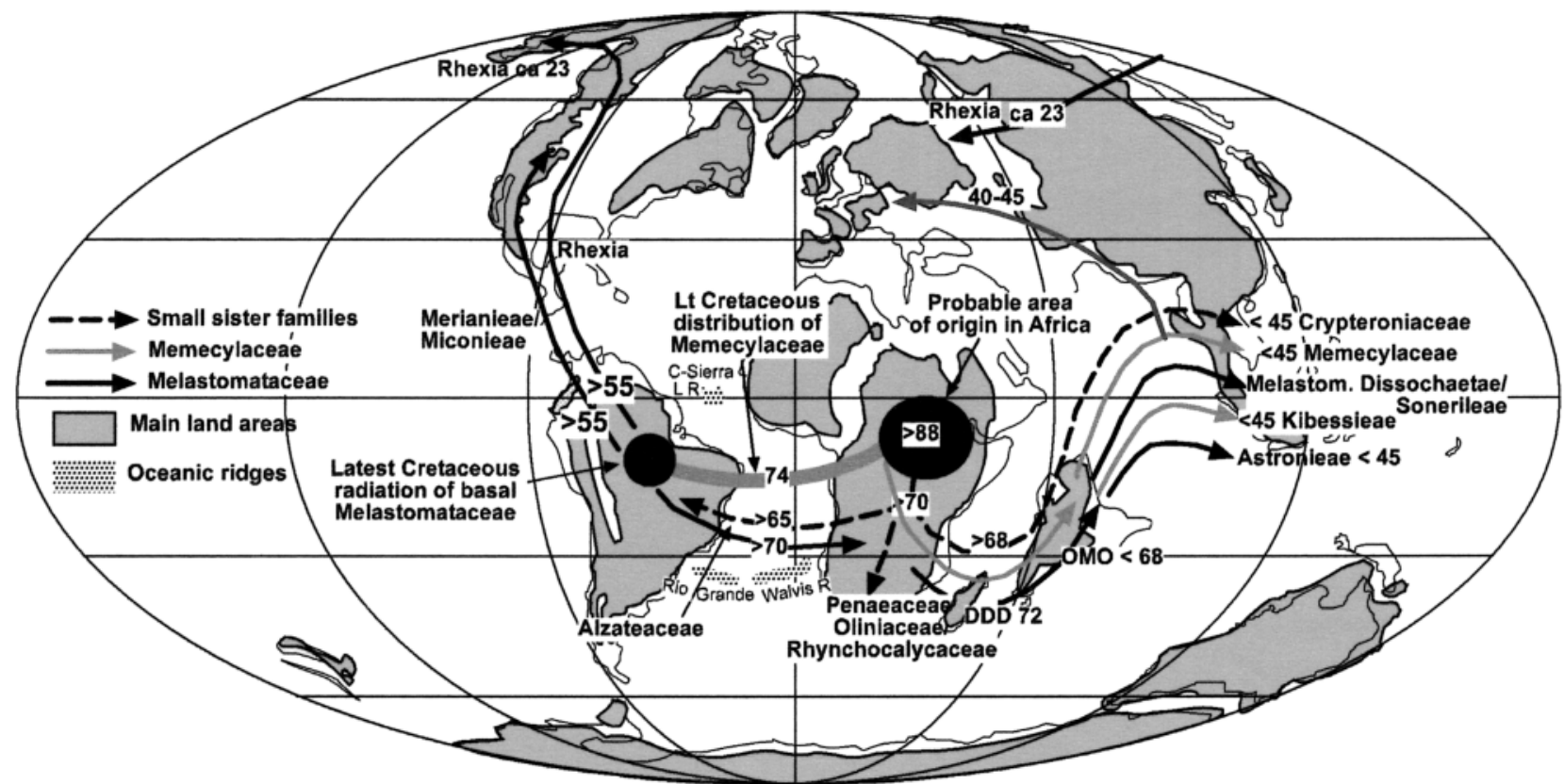

Fig. 2. Origin and dispersal of Melastomataceae. Only "preferred" routes discussed in text are shown. Base map for latest Cretaceous (Maastrichtian, 74$65 \mathrm{Ma}$ ) from Smith et al. (1994), with main land areas shaded; projection type is Mollweide's equal area. DDD = differentiation of Madagascan Dichaetanthera, Dionychia, and Dissotis from African Melastomastrum/Tristemma at about $72 \mathrm{Ma}$, whereas OMO indicates differentiation of Osbeckia, Melastoma, and Otanthera on the Indian Plate after $68 \mathrm{Ma}$ or in Southeast Asia after 45 Ma. C Sierra L R = Ceara-Sierra Leone Rise.

\section{DISCUSSION}

Biogeographical reconstruction-Basal Melastomataceae and sister taxa-Whether we look at its closest relatives or Melastomataceae itself, the cladogram of Renner et al. (2001) provides strong support for a Late Cretaceous West Gondwana center of radiation for the Melastomataceae. The sister taxa to Melastomataceae consist of five small families, with representatives in South America (Alzateaceae), southern Africa (Rhynchocalycaceae, Olineaceae, Penaeaceae) and Southeast Asia (Crypteroniaceae) and the pantropical Memecylaceae. Crypteroniaceae (Dactylocladus, a peat swamp tree), has a possible Middle Miocene fossil pollen record in Borneo (Anderson and Muller, 1975; age revised by Morley, 2000 and Morley, in press), whereas fossil leaves of Memecylon are described from the Oligocene of India (Awasthi and Mehrota, 1995) and fossil wood is reported from the Late Eocene of Germany (Gottwald, 1992).

Two "out of Gondwana" dispersal scenarios need to be considered for the Melastomataceae and its sister families:

1) Origin in South America-Under this scenario, the ancestor to South American Alzateaceae/Crypteroniaceae split off from the South African Penaeaceae/Oliniaceae/Rhynchocalycaceae ancestor prior to termination of Late Cretaceous/ Paleocene South American-North American land bridge (minimum $55 \mathrm{Ma}$ ) (Bonaparte, 1984; Pindall et al., 1988; Hallam, 1994) and prior to termination of trans-oceanic dispersal routes between equatorial Africa and South America (84-65 Ma) (McDougal and Douglas, 1988; Morley, 2000, p. 256) at a time between the Campanian (approximate time of onset of rain forest climates in equatorial South America [ca. $84 \mathrm{Ma}$, but possibly earlier; Morley, 2000]) and the Paleocene (termination of Central American land bridge). The Alzateaceae/ Crypteroniaceae ancestors were able to disperse across the Central American land bridge in Maastrichtian/Paleocene and become part of the Paleocene/Eocene Boreotropical (North America + Eurasia) flora. Crypteroniaceae would have found refuge subsequently in Southeast Asia in Yunnan (Crypteronia) and as an element of Bornean peat swamp floras (Dactylocladus); Alzateaceae found refuge in South America.

2) Origin in Africa-Under this scenario (Fig. 2), the immediate ancestor to Crypteroniaceae/Alzateaceae was in Africa in the latest Late Cretaceous (84-68 Ma) and dispersed to the Indian Plate (before $68 \mathrm{Ma}$ ) and subsequently to Southeast Asia after $45 \mathrm{Ma}$ (via the Indian ark) and is now relict as Crypteroniaceae in Southeast Asia, similarly dispersing from Africa to South America before approximately $65 \mathrm{Ma}$, where it is now relict as Alzateaceae. The ancestral group became extinct in Africa. This scenario is strongly supported by a recent molecular evaluation of Crypteroniaceae by Conti et al. (2002). It is also the simplest, and no fossils of Crypteroniaceae have been recorded from the intensively studied North American/Eurasian Boreotropical floras. Melastomataceae and its sister families therefore are likely to have originated in Africa.

Origin of Memecylaceae-The greatest morphological diversity of Memecylaceae lies in tropical Africa, with Mouriri in South America, and Memecylon having representatives in Africa, Madagascar, and Southeast Asia. This strongly suggests that Memecylaceae had an African-South American distribution in the latest Cretaceous (ca. $74 \mathrm{Ma}$ ), but Memecylon subsequently dispersed via the Indian Plate to Southeast Asia (Fig. 2). The Late Eocene record of Memecylon wood from Germany postdates the collision of the Indian Plate with Asia, and for such Eurasian occurrences, dispersal from the Indian Plate is the simplest explanation.

By tying the cladogram of Melastomataceae + sister families to the timing of dispersal corridors, the sister families 
appear to represent a complex of relict groups that differentiated at an early stage, shortly after the time of domination of angiosperms over other plant groups. The presence of tricolporate pollen in Alzateaceae may be seen as testimony to this initial stage of differentiation, prior to the latest Cretaceous appearance of heterocolpate pollen in the fossil record. The strong representation of sister families in South Africa strongly suggests Africa as an early area of differentiation with subsequent dispersal to Asia via India and to South America. Such an origin would fit well with the history of the related family Myrtaceae, which has its oldest fossils (pollen) in Africa.

Biogeography of the Melastomataceae-Kibessieae (which includes Pternandra) appears from the cladogram to be a sister group to Memecylaceae and is found only in Southeast Asia, suggesting that it differentiated on the Indian Plate after separation from Madagascar (68-45 Ma) or in Southeast Asia after $45 \mathrm{Ma}$.

With respect to subsequent branching, which takes into account the major part of Melastomataceae excluding Kibessieae; most of the basal groups are South American with subsequent branching relating to differentiation in Africa, Madagascar, and Southeast Asia. This suggests that the primary radiation of Melastomataceae may have been in South America during the latest Cretaceous. The Southeast Asian group Astronieae, on the other hand, appears to have had the same history as Memecylaceae, with differentiation on the Indian Plate (68-45 Ma). Such a dispersal pattern would be consistent with Astronia leaf fossils from the Southeast Asian Neogene (Geyler, 1887; Krausel, 1929).

The South American Merianieae/Miconiaeae need to have been well established by the Paleocene, before the closure of the Central American land bridge (55 Ma) in order for members of this group to disperse to North America, thus accounting for North American leaf fossils that compare with this group. Such a dispersal would fit admirably with the Early Eocene appearance of leaves of this type in the western interior of the USA. There is no evidence to suggest that this group dispersed into Eurasia.

Subsequent dichotomies within Melastomeae and Dissochaeteae/Sonerileae can be explained, with the exception of Rhexia, by dispersals from South America via Africa and Madagascar to Southeast Asia. Under this scenario, basal groups must have been in place in South America between about 78 and $74 \mathrm{Ma}$. In Melastomeae, dichotomies occur in geographical sequence suggesting dispersal to Africa prior to about $74 \mathrm{Ma}$, with subsequent differentiation of Madagascan Dichaetanthera, Dionycha, and Dissotis (about $72 \mathrm{Ma}$ ) from African Melastomastrum/Tristemma followed by Osbeckial Melastoma/Otanthera on the Indian Plate (68-45 Ma) or in Southeast Asia (after $45 \mathrm{Ma}$ ). Such a pattern fits admirably with dispersal and differentiation on the Indian Plate prior to collision with Asia in the Middle Eocene.

The widespread occurrence of Melastomeae seeds in Miocene sites from Belgium to Siberia can be explained in two possible dispersal scenarios: (1) Dispersal of a member of Melastomeae to North America via the Central American land bridge (prior to $55 \mathrm{Ma}$ ), which subsequently dispersed either across the short-lived Late Paleocene/Early Eocene southern Greenland land bridge (ca. $56 \mathrm{Ma}$ ) or via Beringia into Eurasia (Fig. 2). The ecology of this group may have been different from that of the Miconieae/Merianieae members, with the result that it has left its fossil record in the form of seeds rather than leaves. This Boreotropical-derived element may still be extant in North America, where Rhexia forms the only temperate-adapted member of the family. Surprisingly, no Melastomeae seed fossils have been reported from the intensively studied European Eocene, possibly giving strength to a mid-Tertiary dispersal of temperate-adapted taxa via Beringia. (2) Because all Melastomeae fossils are Miocene, postdating the collision of India with Asia by $20 \mathrm{Ma}$, this group could simply have dispersed from Southeast Asia or the Indian Plate and may never have been an element of the early Tertiary Boreotropical flora. If this scenario is correct, Rhexia would have dispersed to North America either with ancestral Merenieae/Miconieae toward the end of the Paleocene, and is now relict to the warm temperate forests of southeastern USA (but has left no fossil record), or dispersed across the Isthmus of Panama during the Pliocene, in which case it is currently undergoing a phase of range expansion. We prefer scenario 1, with dispersal to Eurasia via Beringia, in view of the temperate adaptation of Rhexia.

The Dissochaeteae/Sonerileae lineage could be explained in a similar manner to low latitude Melastomeae with dispersal from South America via Africa (between $76 \mathrm{Ma}$ and $70 \mathrm{Ma}$ ) and the Indian Plate (68-50 Ma) to Southeast Asia (after 45 $\mathrm{Ma}$ ), but to understand their cladogram it must be borne in mind that this group (and other rain forest lianas, epiphytes, and ground flora elements) is poorly represented today in Africa, possibly because of African late Tertiary extinction as a result of intermittent dry climates and geological factors (Morley, 2000). With descendants of African contributors to this evolutionary lineage without any representatives, Madagascan and Southeast Asian lines link directly with the South American Blakeeae. An anomaly in this cladogram is the apparent late differentiation of Medinilla into Southeast Asian and Madagascan clades. If this reflects dispersal of Medinilla from the former area of Southeast Asian members of this genus (which may have included the Indian Plate), this dispersal could have taken place any time after about $68 \mathrm{Ma}$.

We wish to stress that the times of separation of continents as accepted by geologists are not necessarily the times of cessation of interplate plant dispersal. Although geological evidence clearly points to "separation" of South America and Africa by the end of the Albian, many new angiosperm pollen types appeared at approximately the same time in both continents throughout the Late Cretaceous (Morley, 2000, p. 88) suggesting continued trans-Atlantic dispersal, possibly via island chains such as the Rio-Grande Rise-Walvis Ridge (McDougal and Douglas, 1988) and Ceara-Sierra Leone Rise (Hallam, 1994). The proportion of simultaneous appearances either side of the Atlantic dropped off from the Maastrichtian onward, as the Atlantic widened, although dispersals continued on a regular basis until the Middle Eocene (Morley, 2000 , p. 255). Similarly, for Africa, Madagascar, and the Indian Plate, the pollen record suggests that plant dispersals continued on a regular basis, presumably via island chains, until the "mid"-Maastrichtian, when they suddenly ceased. The "time window" for dispersal of wet climate plants between South America, Africa, Madagascar, and India was thus from $84 \mathrm{Ma}$ or thereabouts, up to the mid-Maastrichtian (68 Ma). The suggestion by Renner et al. (2001) that undiscovered fossils need to be nine times older than current oldest fossils to push back estimates to 90-100 Ma "for entry into Africa and Madagascar" (p. 1297) is puzzling, for these dates 
are only twice the age of the oldest North American fossils and three times the age of the oldest South American ones.

According to our interpretation of the Renner et al. (2001) data, taking into account the fossil record on the one hand and calibrating the molecular clock by placing divergences in relation to the pattern of well-established and dated dispersal corridors/paths on the other, the Melastomataceae, with its great concentration of diversity in South America, is a family that has had a history essentially within the equatorial zone, with occasional episodes of expansion into the Northern Hemisphere Boreotropical province at times of globally warm climates, especially during the Late Paleocene/Early Eocene thermal maximum. This is a pattern followed by other families that radiated from equatorial (Gondwana) rather than mid-latitudes, such as Annonaceae and Myristicaceae (Morley, 2001). Dispersals were primarily along well-established dispersal paths, perhaps with "island hopping" for taxa that are dispersed by birds or wind. Our analysis indicates that these dispersal routes and the paucity of Gondwana plant fossils should be key considerations in reconstructing biogeographic history of pantropical rain forest taxa.

\section{LITERATURE CITED}

Anderson, J. A. R., AND J. Muller. 1975. Palynological study of a Holocene peat and a Miocene coal deposit from N.W. Borneo. Review of Palaeobotany and Palynology 19: 291-351.

Awasthi, N., And R. C. Mehrota. 1995. Oligocene flora from Makum Coalfield, Assam, India. Palaeobotanist 44: 157-188.

Bande, M. B., And U. Prakash. 1986. The Tertiary flora of Southeast Asia with remarks on its palaeoenvironment and phytogeography of the Indo-Malayan region. Review of Palaeobotany and Palynology 49: 203-233.

Berggren, W. A., D. V. Kent, C. C. Swischer III, AND M.-P. Aubrey. 1995. A revised Cenozoic geochronology and chronostratigraphy. In W. A. Berggren, D. V. Kent, and J. Hardenbol [eds.], Geochronology, time scales and global stratigraphic correlations: a unified temporal framework for a historical geology. SEPM Special Publication 54: 129-212.

BONAPARTE, J. F. 1984. Late Cretaceous faunal interchanges of terrestrial vertebrates between the Americas. In W. E. Reif, and F. Westphal [eds.], Third symposium on Mesozoic terrestrial ecosystems, 19-24. Attempo, Tubingen, Germany.

Burnham, R. J., AND A. Graham. 1999. The history of Neotropical vegetation: new developments and status. Annals of the Missouri Botanic Garden 86: 546-589.

Collinson, M. E. 1990. Plant evolution and ecology during the early Cenozoic diversification. Advances in Botanical Research 17: 1-98.

Collinson, M. E., And M. Pingen. 1982. Seeds of the Melastomataceae from the Miocene of Central Europe. In J. Kovar-Eder [ed.], Palaeovegetational development in Europe, 129-139. Museum of Natural History, Vienna, Austria.

Conti, E., T. ERIKSSON, J. Schönenberger, K. J. Sytsma, AND D. BAum. 2002. Early Tertiary out-of-India dispersal of Crypteroniaceae: evidence from phylogeny and molecular dating. Evolution 56: 1931-1942.

Duarte, L. 1956. Melastomatáceas fósseis da Bassia Tertiária de Fonseca, Minas Gerias. Divisão de Geologia e Minerologia Boletim 161: 8-32.

Gaut, B. S., L. G. Clark, J. F. Wendel, and S. V. Muse. 1997. Comparisons of the molecular evolutionary process at $r b c \mathrm{~L}$ and $n d h \mathrm{~F}$ in the Grass family (Poaceae). Molecular Biology and Evolution 14: 769777.

GeNTRY, A. H. 1982. Neotropical floristic diversity: phytogeographical connections between Central and South America, Pleistocene climatic fluctuations or an accident of Andean orogeny? Annals of the Missouri Botanical Garden 69: 557-93.

Geyler, T. T. 1887. Uber fossil Pflanzen fon Labuan. Vega Expedition Vertenskaper Arboretum 4: 475-507.

GotTwald, H. 1992. Hölzer aus marinen Sanden des Oberen Eozen von Helmstedt (Niederlandischen). Palaeontographica, Abt B 255: 27-103.
Hallam, A. 1994. An outline of Phanerozoic biogeography. Oxford Biogeography Series No. 10. Oxford University Press, Oxford, UK.

Harland, W. B., R. A. Armstrong, A. V. Cox, L. A. Craig, A. G. Smith, AND D. G. Sмith. 1989. A geological time scale. Cambridge University Press, Cambridge, UK.

HiCKEY, J. L. 1977. Stratigraphy and palaeobotany of the Golden Valley Formation (Early Tertiary) of western North Dakota. Geological Society of America Memoir 150. Geological Society of America, Boulder, Colorado, USA.

Huertas, G. 1977. Una Melastomatácea fósil del Terciario carbonifero de Antioquia (Eoceno). Caldasia 12: 35-39.

JaCques-FÉlix, H. 1994. Histoire des Melastomataceae d=Afrique. Bulletin du Museum National d=Histoire Naturelle, Paris, 4e sér., 16, sect. B, Adansonia 2-4: 235-311.

Krausel, B. 1929. Fossile Pflanzen aus dem Tertiär von Sud Sumatra. Verhandelingen der Geologie en Mijnbouw Genootschap voor Nederland en kolonien, Geologie Serie 8: 329-342.

Kumar, S., K. Tamura, I. B. Jakobsen, and M. Nei. 2001. MEGA2: molecular evolutionary genetics analysis software. Bioinformatics 17: 12441245.

LI, W.-H., C.-L. WU, AND C.-C. LuO. 1985. A new method for estimating synonymous and nonsynonymous rates of nucleotide substitution considering the relative likelihood of nucleotide and codon changes. Molecular Biology and Evolution 2: 150-174.

MAI, D. H. 2000. Die untermiozänen Floren aus der Spremberger Folger und dem II Flözhorizont der Lausitz. Teil III. Dialypetalae und Sympetalae. Palaeontographica Abt B 253: 1-106.

MANCHESTER, S. R. 1999. Biogeographical relationships of North American Tertiary floras. Annals of the Missouri Botanical Garden 86: 572-522.

McDougal, I., And R. A. Douglas. 1988. Age-progressive volcanism in the Tasmanitid seamounts. Earth and Planetary Science Letters 89: 207220.

Morley, R. J. 2000. Origin and evolution of tropical rain forests. John Wiley $\&$ Sons, West Sussex, UK.

MoRLEY, R. J. 2001. Why are there so many primitive angiosperms in the rain forests of the Far East. In I. Metcalfe, J. M. B. Smith, M. Morwood, and I. Davidson [eds.], Faunal and floral migrations and evolution in SE Asia-Austalia 185-200. Balkema, Lisse, Netherlands.

Morley, R. J. In press. Ecology of Tertiary coals in SE Asia. In T. A. Moore [ed.], Coal geology of Indonesia: from peat formation to oil generation. Advances in Sedimentology series. Elsevier, Amsterdam, Netherlands.

MulLER, J. 1975. Notes on pollen morphology of Crypteroniaceae s.l. Blumea 22: 275-294.

MulLeR, J. 1981. Fossil pollen records of extant angiosperms. Botanical Review 47: 1-142.

MusE, S. V., AND B. S. GAUT. 1997. Interlocus comparisons of the nucleotide substitution process in the chloroplast genome. Genetics 146: 393-399.

Pindall, J. L., S. C. Cande, W. C. Pitmann, D. B. Rowley, L. F. Dewey, J. LABReCQUE, AND W. HAXBY. 1988. A plate-kinematic framework for models of Caribbean evolution. Tectonophysics 155: 121-138.

RaO, K. P., and C. G. K. Ramanujam. 1982. Palynology of the Quillon Beds of Kerala State in South India II-pollen of dicotyledons and discussion. Palaeobotanist 30: 68-100.

Raven, P. H., AND D. I. AXELROD. 1974. Angiosperm biogeography and past continental movements. Annals of the Missouri Botanical Garden 61: 39-637.

RenNeR, S. S. 1993. Phylogeny and classification of the Melastomataceae and Memecylaceae. Nordic Journal of Botany 13: 519-540.

Renner, S. S., G. Clausing, AND K. Meyer. 2001. Historical biogeography of Melastomataceae: the roles of Tertiary migration and long-distance dispersal. American Journal of Botany 88: 1290-1300.

Renner, S. S., AND K. MeYer. 2001. Melastomataceae come full circle: biogeographic reconstruction and molecular clock dating. Evolution 55: $1315-1324$.

Salard-ChebaldaefF, M. 1981. Palynologie maestrichtienne et tertiare du Cameroun. Results botanique. Review of Palaeobotany and Palynology 32: 401-39.

Smith, A. G., D. G. Smith, And M. Funnel. 1994. Atlas of Mesozoic and Cenozoic coastlines. Cambridge University Press, Cambridge, UK.

van der Hammen, T. and C. Garcia de Mutís. 1966. The Paleocene pollen flora of Colombia. Leidse Geologische Mededelingen 35: 105-116.

van der Hammen, T. and E. Gonzaléz Guzman. 1963. Historia de clima 
y vegetaciün del Pleistoceno superior del Holoceno de la Sabana de Bogotá. Boletín Geologico (11) 1-3: 189-266.

WeHR, W. C., AND D. Q. HopkINS. 1994. The Eocene orchards and gardens of Republic Washington. Washington Geology 22: 27-34.

Wolfe, K. H., W.-H. Li, AND P. M. Sharp. 1987. Rates of nucleotide substitution vary greatly among plant mitochondrial, chloroplast, and nuclear
DNAs. Proceedings of the National Academy of Sciences USA 84: 90549058.

Zurawski, G. T., AND M. T. ClegG. 1987. Evolution of higher-plant chloroplast DNA-encoded genes: implications for structure-function and phylogenetic studies. Annual Review of Plant Physiology 38: 391-418. 